\title{
Ground support installations, using a mechanised unroller and flexible high-tensile strength chain link mesh
}

\author{
G Fischer Geobrugg Andina SA, Chile \\ J Ruiz-Tagle Salfa Montajes, Chile \\ R Bucher Geobrugg Australia Pty Ltd, Australia \\ R Luis Geobrugg AG, Switzerland
}

\begin{abstract}
Traditional support and reinforcement systems used in underground mining are limited in their capacity under dynamic loading. Static and dynamic tests carried out by the Western Australian School of Mines have shown that high-tensile chain link mesh has much higher capacity under dynamic loading. Therefore, the high-tensile steel wire ( $\min 1,770 \mathrm{MPa})$ and the flexibility of the chain link mesh, makes this a support system to be applied in areas with very high static and dynamic expected loading. Historically, ground support processes were done manually. A device has been developed that is mounted on one of the booms of a jumbo and/or bolting machine, which will allow a more efficient installation of the support systems. This unroller device is compatible and retro-fittable with most multiple boom drill jumbo's and allows installation of rhomboidal high-tensile steel chain link mesh from rolls. While the one boom on the bolter is fitted with a drilling and bolting device, the mesh can be installed using the other arm. This innovative and mechanised installation of chain link mesh provides an increase in miners' safety and improves production performance of the mine. This paper referred to two examples of automated application of meshes mesh installation trials performed at El Teniente mine (Chile) and Goldfields South Deep mine (South Africa).
\end{abstract}

Keywords: sustainability, high-tensile steel chain link mesh, automation, performance, roof support

\section{Introduction}

Undoubtedly, safety and productivity in the work of underground mining is an increasingly imperative. The need to use new products and technologies to ensure that these factors are part of the daily activity of the mine is one of the basic objectives of this applied research work. In the modern world, technological innovation with products and new methodologies application has been the natural way of providing solutions. In this particular case the product is a high-tensile steel wire mesh, with an unprecedented response to dynamic loads. The aim of this case study is to prove the ability of this unroller device and the stronger mesh, to be able to install the ground support faster and possibly reduce the number of bolts required.

\section{Product: high-tensile chain link mesh}

The high-tensile wire (1,770 MPa) mesh offers a surface support for most ground conditions. The mesh is made from high-tensile steel wire with a diameter of 4 and/or $3 \mathrm{~mm}$. The mesh has a specific developed diamond shape to minimise deformations and along the edges, the wires are looped and twisted back on itself (Figure 1). This enables the edge of the mesh having the same loading capacity as the mesh (Luis Fonseca, R. et al 2009). Both mesh types are produced in rolls, which reduces the storage space, and can be manufactured in widths of up to $3.5 \mathrm{~m}$ and in tailor-made lengths corresponding to the tunnel surface to be meshed. Due to the use of high-tensile wire, the mesh is very light in relation to its strength (MINAX ${ }^{\circledR} \mathrm{G80} / 4$ $-2.6 \mathrm{~kg} / \mathrm{m}^{2}$ and MINAX ${ }^{\oplus}: \mathrm{G} 80 / 3-1.45 \mathrm{~kg} / \mathrm{m}^{2}$ ). In terms of corrosion protection, the wires are coated with a special aluminium-zinc coating, which has a higher corrosion resistance than standard galvanising. 
Comparison tests, based on standardised salt spray tests, show that this wire lasts at least three to four times longer under such conditions than conventional galvanised wire.
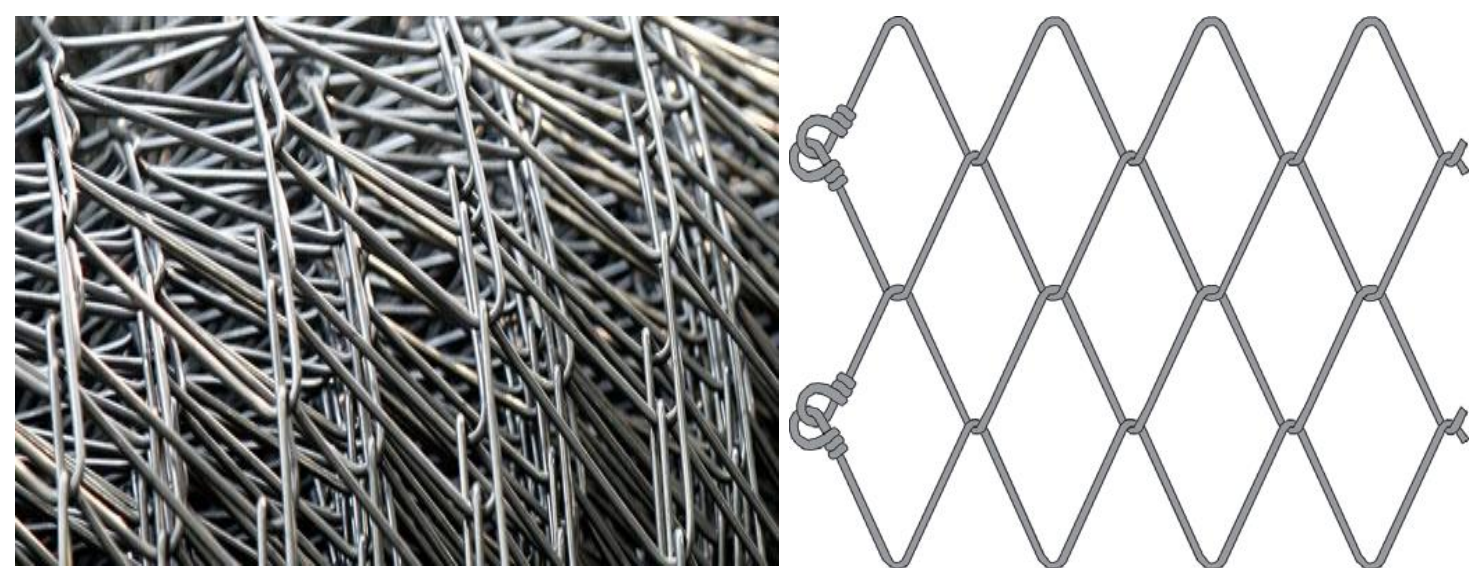

Figure 1 Geometry of the high tensile steel wire mesh

The strength of the wire and the strength in the bends prevent it from unravelling upon a dynamic impact. The resistance properties of the mesh were determined in a series of laboratory tests at the University of Cantabria, Spain (Unican 2002). The properties of the meshes MINAX ${ }^{\circledR}$ G80/4 and MINAX ${ }^{\circledR}$ G80/3 are summarised in Table 1.

Table 1 Properties of the high-tensile mesh

\begin{tabular}{lll}
\hline Material & MINAX $^{\circledR}$ G80/4 & MINAX $^{\circledR ~ G 80 / 3 ~}$ \\
\hline Mesh width & $80 \mathrm{~mm}$ & $80 \mathrm{~mm}$ \\
Diagonal & $102 \times 177 \mathrm{~mm}$ & $103 \times 180 \mathrm{~mm}$ \\
Wire diameter & $4 \mathrm{~mm}$ & $3 \mathrm{~mm}$ \\
\hline Wire strength & $1,770 \mathrm{MPa}$ & $1,770 \mathrm{MPa}$ \\
\hline Breaking load of wire & $22 \mathrm{kN}$ & $12.5 \mathrm{kN}$ \\
\hline Tensile strength & $190 \mathrm{kN} / \mathrm{m}$ & $110 \mathrm{kN} / \mathrm{m}$ \\
\hline Weight & $2.6 \mathrm{~kg} / \mathrm{m}^{2}$ & $1.45 \mathrm{~kg} / \mathrm{m}^{2}$ \\
\hline
\end{tabular}

A special designed spike plate has been designed in order to increase the transfer loads from the mesh through the spike plate to the anchoring system. The plates are made out of $5 \mathrm{~mm}$ thick galvanised steel and have a shape that best fits the mesh. The spike plate grabs the mesh in six positions plus the rockbolt in the centre. The three dimensional shape results in it having a high overall stiffness.

\subsection{Testing and modelling of high-tensile chain link mesh}

In order to determine the mechanical properties of the mesh, MINAX was extensively tested under quasi-static and dynamic loading conditions, at the Western Australian School of Mines (WASM). For the dimensioning of the support system consisting of mesh and bolts, a finite element numerical model was developed, calibrated and verified by the Swiss Federal Research Institute (Roth et al. 2004).

\subsubsection{Static testing}

The static response of high-tensile chain link mesh was determined by test work in the WASM laboratory in Kalgoorlie. Figure 2 shows the response of three samples of the high-tensile G80/4 mesh where a $1.3 \times 1.3 \mathrm{~m}$ panel was loaded with a $300 \times 300 \mathrm{~mm}$ steel plate. The test setup is described by Morton et al. (2007). 

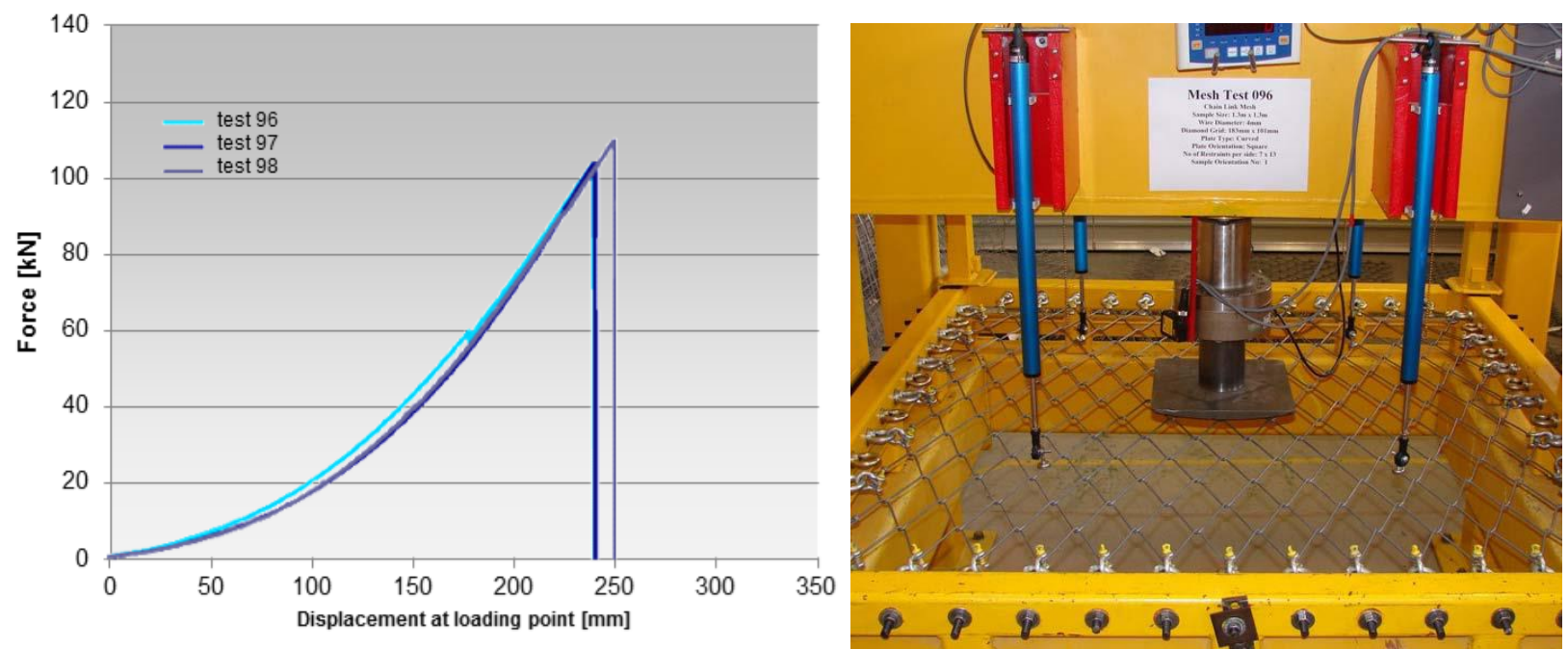

Figure 2 Measured forces in the anchorages for the high tensile steel mesh G80/4

The high-tensile mesh was able to bear a load of up to $110 \mathrm{kN}$ before it failed at the edge of the loading plate. Weld mesh $(5.6 \mathrm{~mm}, 100 \times 100 \mathrm{~mm})$, in comparison, failed with $43 \mathrm{kN}$, and mild steel chain link failed with less than $20 \mathrm{kN}$, using the same test setup. For the heavy mild steel chain link mesh $(5 \mathrm{~mm}$ diameter, mesh width $100 \mathrm{~mm}$, tensile strength $460 \mathrm{MPa}$ ), failure occurred at 30 to $40 \mathrm{kN}$ due to the ending knots at the mesh border according to the test report (Villaescusa 2009). After closing the ends with wire rope clips (Figure 3), breakage occurring at 60 to $70 \mathrm{kN}$ (see Figure 3(a)) with displacements around $370 \mathrm{~mm}$ at peak load.

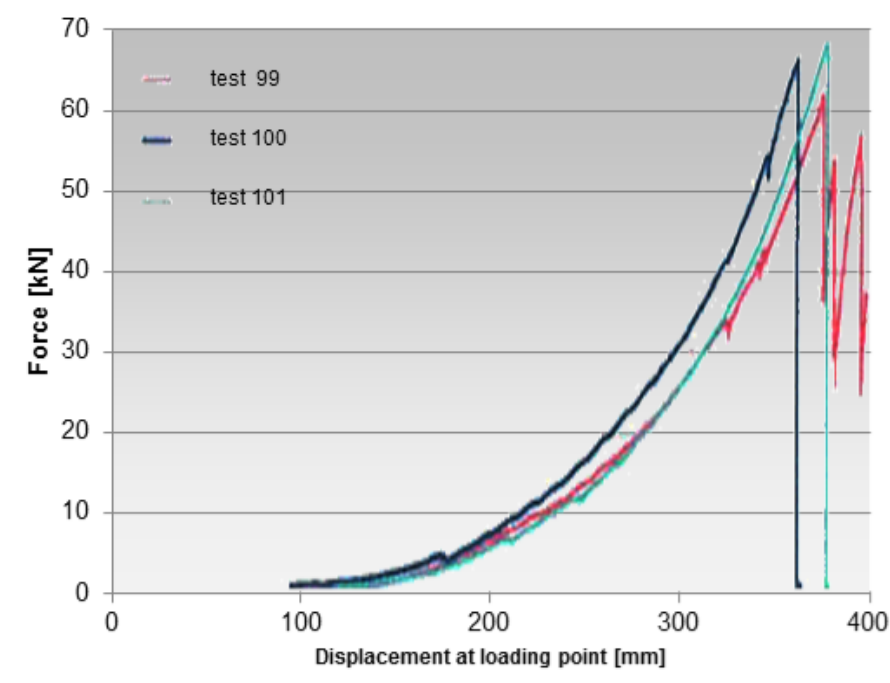

(a)

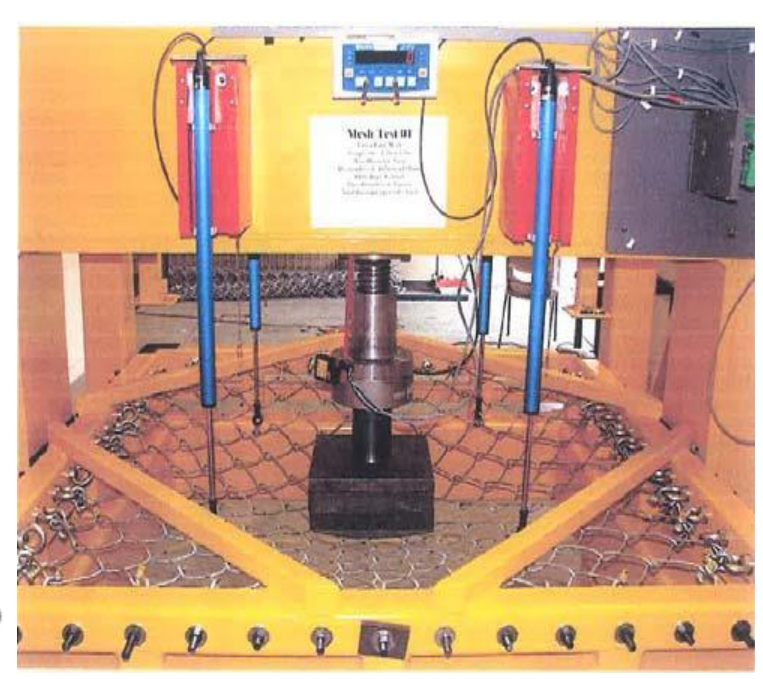

(b)

Figure 3 Measured forces in the anchorages for the $5 \mathrm{~mm}$ wire diameter heavy mild steel chain-link mesh

The high-tensile chain link mesh MINAX ${ }^{\oplus} \mathrm{G} 80 / 3$ was able to bear a load of up to $50 \mathrm{kN}$ before it failed at the edge of the loading plate (see Figure 4). 

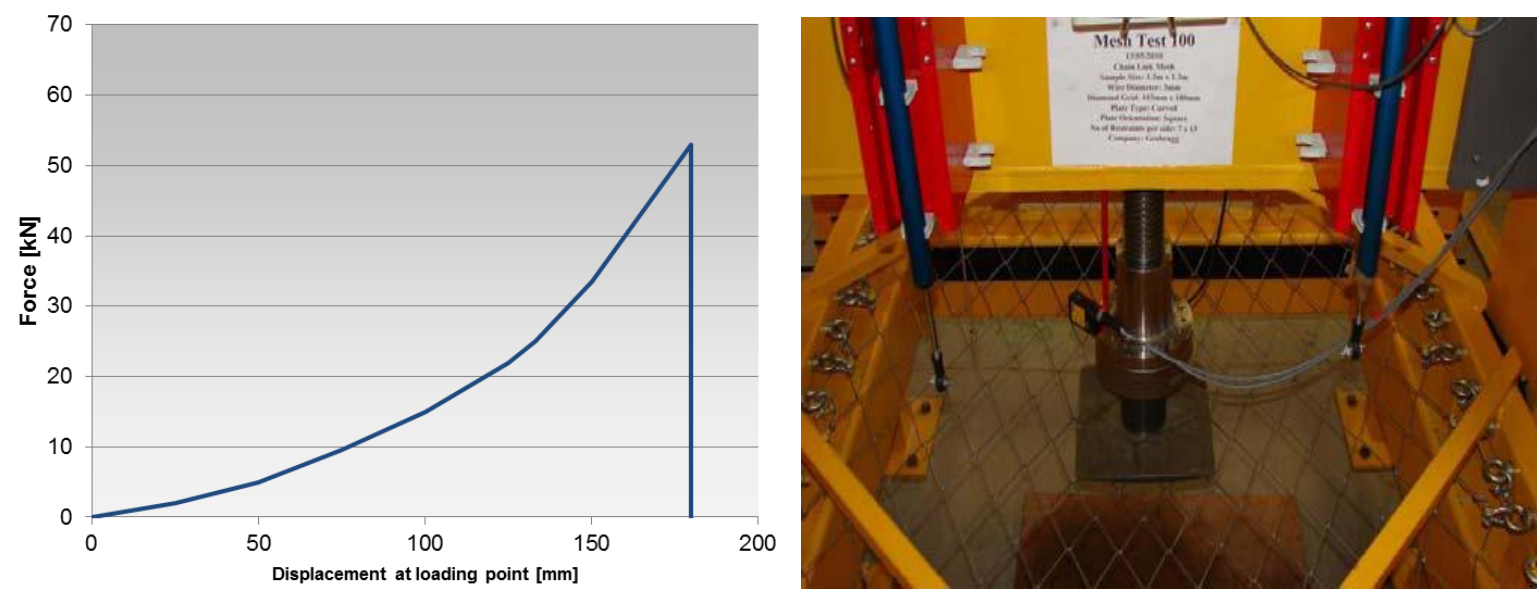

Figure 4 Measured forces in the anchorages for the high-tensile steel mesh MINAX ${ }^{\circledR}$ G80/3

It was also found that the high-tensile chain link mesh can sustain an increase in load, even after a wire has failed. Furthermore, it does not unravel once a wire has failed. In earlier tests, the high-tensile mesh was tested under quasi-static load, whereby the mesh was bolted to the ground by four bolts and plates and a loading plate underneath the mesh was pulled upwards. Based on that test it was established that rupture generally starts at the crossing points, but does not shear at the edge of the plates due to the higher steel quality of the mesh compared to the mild steel plates. Due to previous experience with mild steel chain link mesh, there is always the concern that if one of the chain link mesh strands is broken, the mesh will unravel and open. However, it has been proven that this is not the case for high-tensile chain link mesh, since in the previously described test the mesh was loaded up with one of the wires cut. The test results, capacity and deformation of the high-tensile chain link mesh has been shown to be practically unaffected by the broken wire (Roth et al. 2004), and is shown in Figure 5. This only applies for high-tensile chain link mesh. It does not apply for mild steel chain link mesh, as the individual wire does not have the required strength to lock itself in.

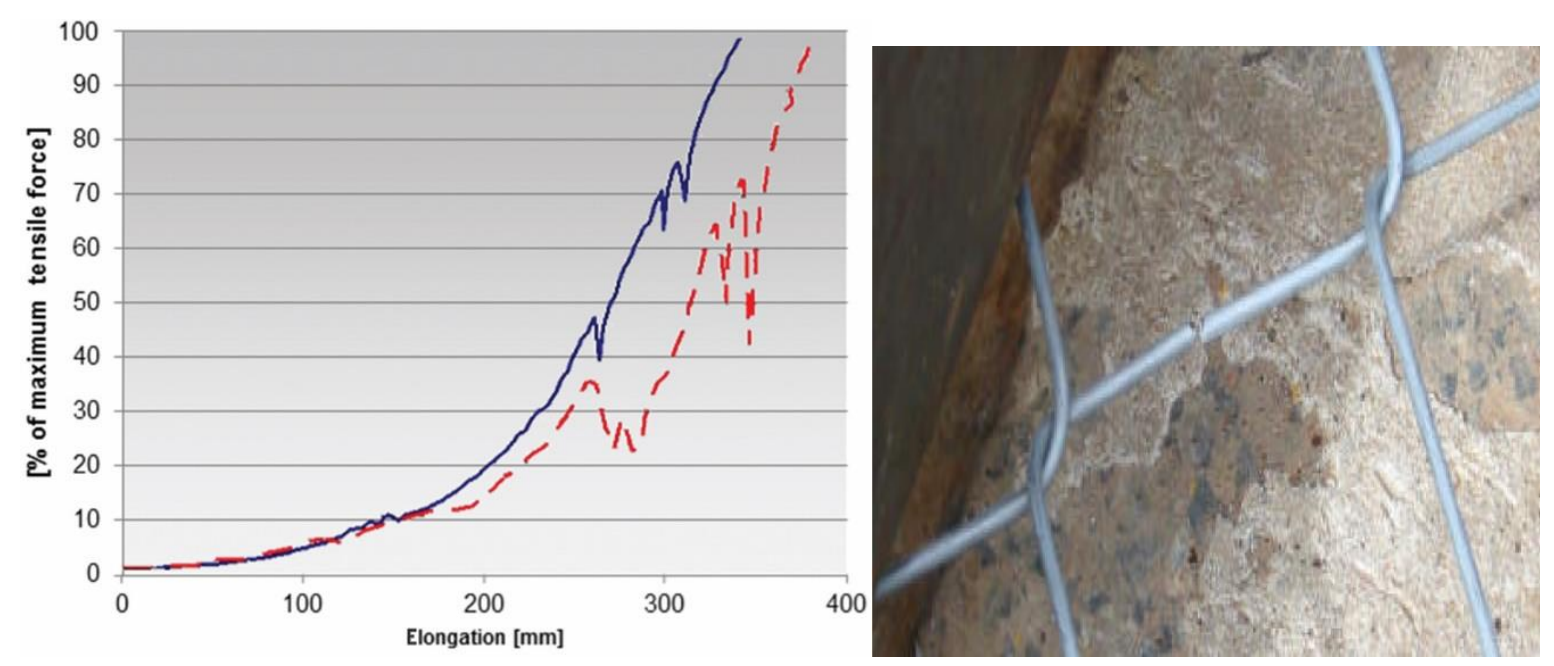

Figure 5 Static tests of a high tensile steel wire mesh that shows no unravelling

\subsubsection{Dynamic testing}

The MINAX ${ }^{\circledR}$ G80/4 mesh was tested at the dynamic testing facility of WASM (Player et al. 2008) by using a momentum transfer method (Player et al. 2004; Thompson et al. 2004). The mesh panel is installed using shackles and eye-bolts in the frame and the weight is placed on top of the mesh. The full system is dropped onto buffers from different heights. When the system hits the buffers everything comes to a sudden stop, except the weight placed on the mesh that keeps decelerating and is loading the mesh dynamically. This is simulating the situation underground where the mesh is placed against the rock mass, which can eject into the surface support (mesh) under dynamic load. The dynamic test apparatus is instrumented with a 
high-speed video camera, load cells and accelerometers. Figure 6 shows images from a camera (Figure 6(a)) and a high-speed video camera (Figure 6(b)) before and after a mass of 1,000 kg (bag with mill steel balls) hits the high-tensile chain link mesh. The mesh deforms with the applied load and transfers the forces to the boundary. The boundary conditions are fixed to have comparable and repeatable results.

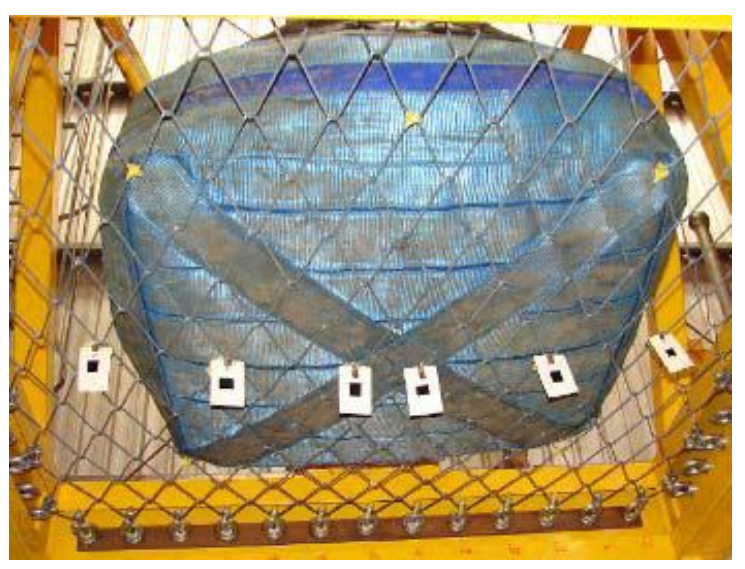

(a)

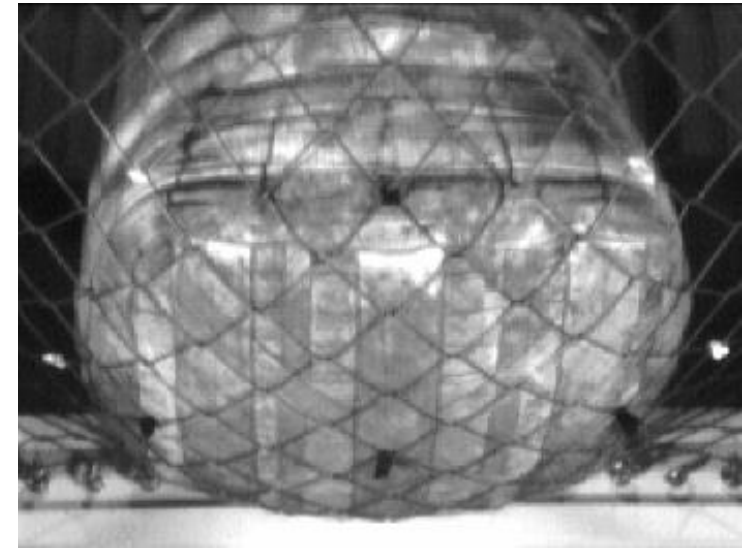

(b)

Figure 6 Photo: (a) from underneath the test arrangement before the impact of a 1,000 kg mass; and, (b) from the high-speed video camera after impact

It was established that the high-tensile chain link mesh MINAX ${ }^{\circledR}$ G80/4 is able to absorb energies of up to $12 \mathrm{~kJ}$ in such a configuration. This is equal to stopping a rock mass of $1,000 \mathrm{~kg}$ that was accelerated to $4.9 \mathrm{~m} / \mathrm{s}$. This value represents the energy absorption of the mesh only and does not include any absorption by the rock mass or the yielding bolts. Welded wires mesh $(5.6 \mathrm{~mm}, 100 \times 100 \mathrm{~mm})$ showed energy absorption capacities up to $2 \mathrm{~kJ}$ in the same test setup.

\section{Installation method: $\mathrm{MESHA}^{\mathrm{TM}}$ device}

The difference between the installation of welded mesh and the installation of chain linked mesh results from the stiffness of the products. The welded wire mesh is relatively stiff and is delivered and applied in sheets. The roll of chain link mesh is only stiff in one direction but flexible in the other and, therefore, needs to be installed in a different way to welded wire mesh. Consequently, a new way was conceived, comprising a mesh handler to unroll the mesh, tensioning and hold it onto the surface of the tunnel while it is pinned to the backs and walls with the second jumbo boom or bolting arm. The main objectives were the speed and safety of the installation in order to comply with the targets of modern mining, both in terms of safety and economics.

\subsection{Fully mechanised installation}

An automated roll mesh handler for the application of high-tensile chain link mesh was developed and successfully tested in Australia and Switzerland for the installation of ground support, in underground developments. The handler called MESHA ${ }^{\mathrm{TM}}$ is compatible with almost all standard multi-boom jumbos and bolting and drilling equipment, applying mesh from a cassette system. The handler with the mesh roll is mounted on the one boom and the drill/bolter mounted on the other boom of the jumbo (Figure 7). The application of the high-tensile mesh and installation of split-sets or bolts occur simultaneously. 

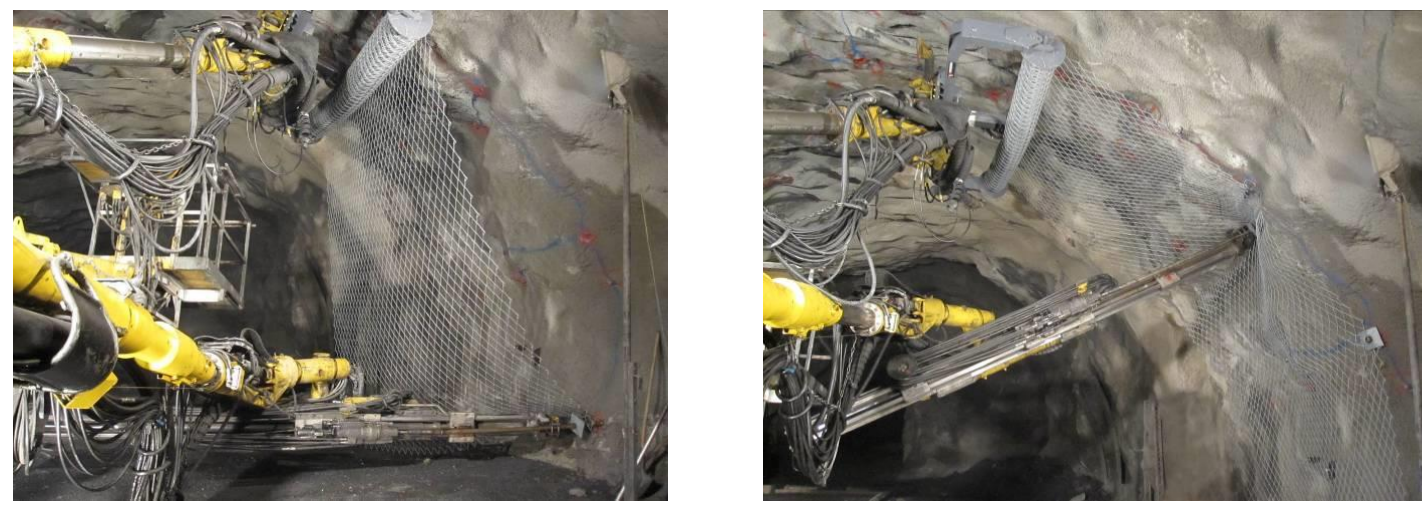

Figure 7 MESHA ${ }^{\mathrm{TM}}$ mounted on a jumbo boom picks up the roll of mesh and makes the bolts at the same time

The handler is manipulated from the cabin of the jumbo to pick up a roll of high-tensile mesh, minimising physical manual handling. The mesh can then be positioned on the walls and backs for bolting, using the drilling component of the opposite boom. The system reduces manual handling and personnel exposure during the installation process, can reduce support cycle times and enables the mesh to follow the rock surface contours more closely reducing unravelling/bagging of material in voids. The chain link structure of the mesh and the spiral Knotted ends allows for a very efficient unrolling process. No personnel are exposed to unsupported ground, due to the ability of the jumbo to pick up the mesh roll cassette with the manipulator arm.

\subsection{In situ installation trial at Goldfields South Deep (South Africa)}

Case studies were carried out at sites: 1B03, 1B11 and Ramp 7 (Tonkin 2011). Three drill rig operators were used in these tests, this was done to eliminate the risk of results being positively or negatively affected by abnormally fast operators or inexperienced operators, respectively. Once times were attained, the top and bottom 15\% were eliminated to get rid of outliers and, thus, minimise the effects of human error and machine defects that would not commonly occur but would heavily affect the mean time and standard deviation. The installation of wire mesh was separated into three different phases and six different sub-phases (Table 2).

Table 2 Phases of the wire meshing

\begin{tabular}{llll}
\hline Phase & No. & Sub-phase & Description \\
\hline Drilling & 1 & Drilling & Drilling of a 3.5 m hole in the hanging wall \\
Preparation & 2 & Split set & Attaching of the split set onto the dolly pusher \\
& 3 & Wire mesh & Attaching mesh to the boomer for installation \\
\hline Attachment & 4 & Positioning & Positioning of the mesh in the desired area and direction \\
& 5 & Locating hole & Lining up of the split set and the hole \\
& 6 & Insertion & Insertion of the split set into the drilled hole \\
\hline
\end{tabular}

Data was taken while considering the following wire meshing pattern (Figure 8).

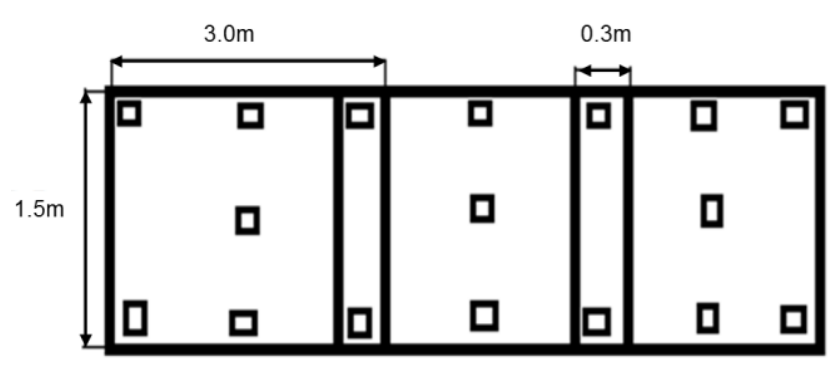

Figure 8 Conventional wire meshing 
The graphs, in Figure 9, describe the operations previously mentioned in Table 2 as a function of time.

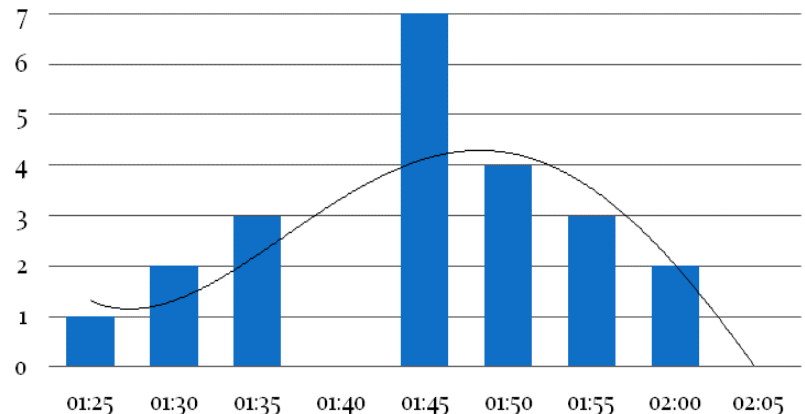

(a)

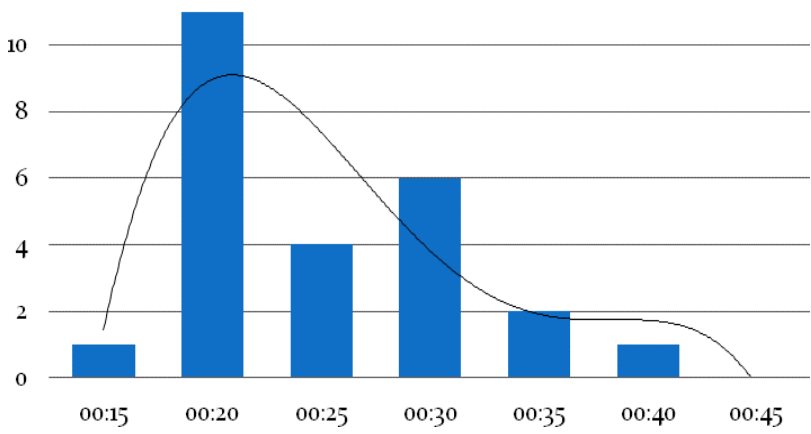

(c)

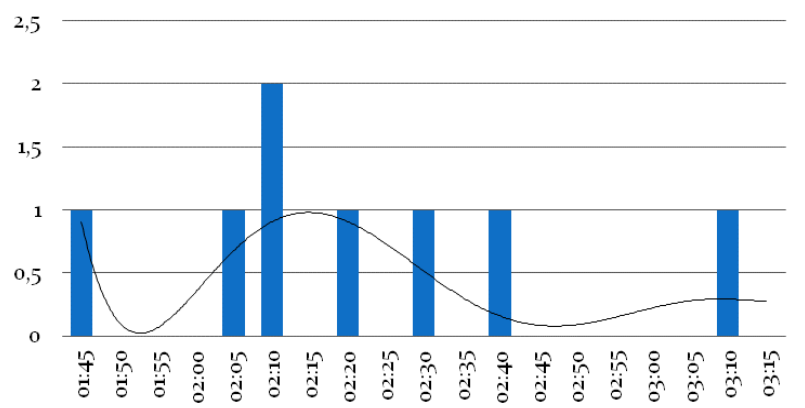

(e)

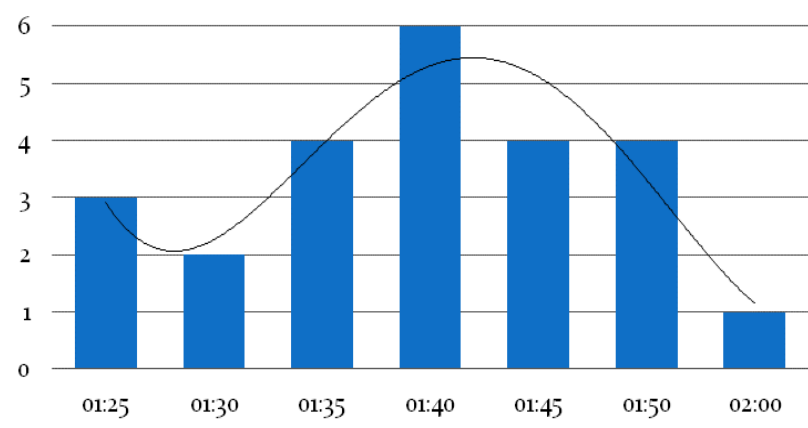

(b)

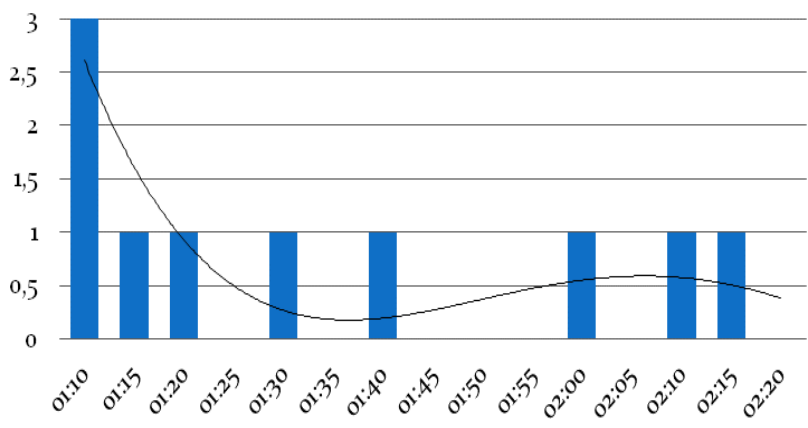

(d)

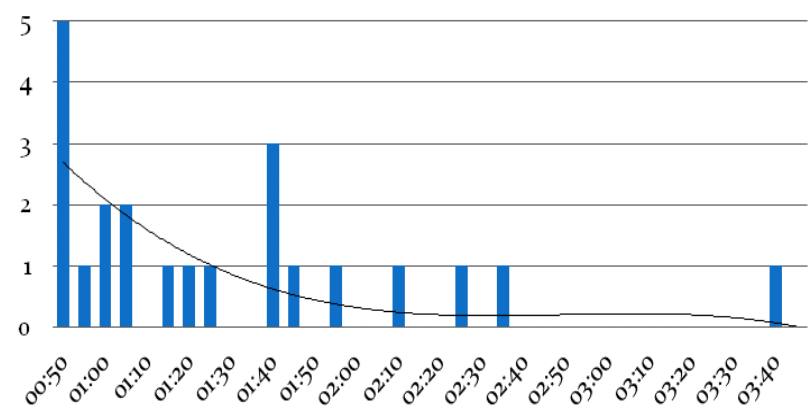

(f)

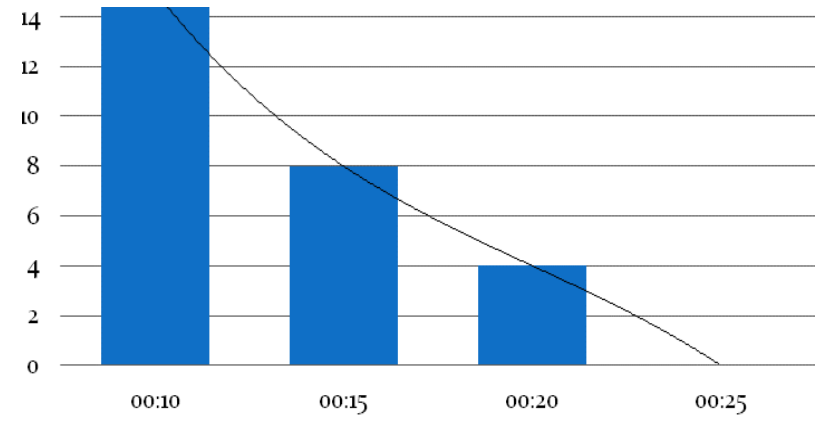

(g)

Figure 9 Phases of the wire meshing: support drilling (a) left boom and (b) right boom; (c) preparation of split sets; (d) preparation of mesh; (e) positioning of mesh; (f) locating of drilled hole; and, (g) insertion of split sets

From the obtained results, the comparison between conventional wire mesh installation and wire meshing that used the MESHA ${ }^{\mathrm{TM}}$ and $\mathrm{MINAX}^{\circledR}$ mesh, developed by Geobrugg ${ }^{\circledR}$, is summarised in Table 3. 
Table 3 Installation using conventional meshing versus MESHA ${ }^{\mathrm{TM}}$

\begin{tabular}{llll}
\hline Activity description & $\begin{array}{l}\text { Conventional } \\
\text { (after 10 shifts) }\end{array}$ & $\begin{array}{l}\text { MESHA }^{\circledR} \\
\text { (estimated after 1 trial) }\end{array}$ & $\begin{array}{l}\text { MESHA } \\
\text { (30\% time reduction) }\end{array}$ \\
\hline Effective support considered & $12.6 \mathrm{~m}^{2}$ & $24 \mathrm{~m}^{2}$ & $24 \mathrm{~m}^{2}$ \\
\hline Expected number of drilled holes & 17 & 35 & 35 \\
\hline Drilling & $02: 21$ & $02: 33$ & $02: 33$ \\
\hline Preparation & $00: 58$ & $00: 48$ & $00: 48$ \\
\hline Attachment & $03: 29$ & $01: 30$ & $01: 25$ \\
\hline Total & $06: 48 \mathrm{~min} / \mathrm{m}^{2}$ & $04: 51 \mathrm{~min} / \mathrm{m}^{2}$ & $04: 46 \mathrm{~min} / \mathrm{m}^{2}$ \\
\hline Hanging wall support & $1: 25: 47$ per shift & $1: 56: 24 \mathrm{per} \mathrm{shift}$ & $1: 54: 24 \mathrm{per} \mathrm{shift}$ \\
\hline Sidewall support & $70 \mathrm{~min}$ per shift & Included & Included \\
\hline Total & $2: 35: 47$ per shift & $1: 56: 24 \mathrm{per} \mathrm{shift}$ & $1: 54: 24 \mathrm{per} \mathrm{shift}$ \\
\hline Time saved per shift & - & $39: 23 \mathrm{~min} / \mathrm{m}^{2}$ & $41: 23 \mathrm{~min} / \mathrm{m}^{2}$ \\
\hline
\end{tabular}

It was assumed that the MESHA ${ }^{\mathrm{TM}}$ did not influence the drilling time. It is assumed that in the future the same drilling pattern as the one used in conventional sheet meshing will be used. To ensure that the same support standards were used for sheet wire meshing and the MESHA ${ }^{\mathrm{TM}}$, it was decided that 10 split sets should be installed on either side of the sidewall, using the same method as those installed in the hanging wall. As Table 3 showed, and because the mesh is composed of high-tensile wire, it can get high performance at a very low unit weight, which certainly helps increase speed and performance during the installation process. The accuracy of the information may be limited by the following factors:

- The attachment times are estimates.

- This was the operators first time using the MESHA ${ }^{\mathrm{TM}}$.

- Different drill rigs were used during the conventional and MESHA ${ }^{\mathrm{TM}}$ installations.

- Hanging wall conditions between relevant workplaces (South shaft, 87, 1 west and Twin shaft, 94, 3 wests) differ.

During the trial the operator stated that the $\mathrm{MESHA}^{\mathrm{TM}}$ seemed to be more effective than conventional meshing and there was no damage noted to the MINAX ${ }^{\circledR}$ G80/3 mesh after blasting. Additionally, with the use of high tensile-strength meshes, the rock face remains visible for inspection.

\subsection{In situ installation - a case study at El Teniente mine (Chile)}

Installations were taken at Brecha area (Salfa Montajes 2015). And, like the Goldfields South Deep case study, more than one drill rig operator was used (Figure 10) in this case study.
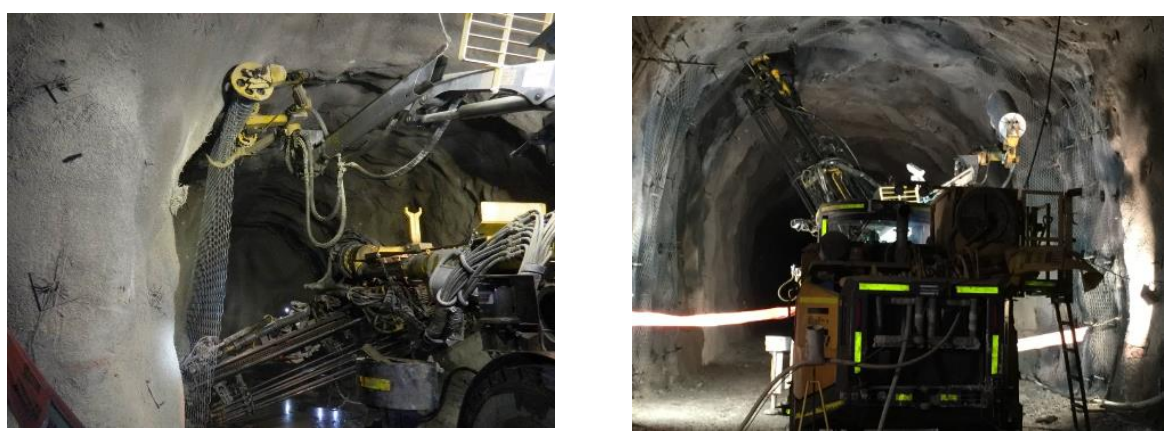

Figure $10 \mathrm{MESHA}^{\mathrm{TM}}$ installations at Codelco facilities in El Teniente 
In this location, the surface support system used was applied in two steps (Figure 11(b)). The first consisted of a layer of $70 \mathrm{~mm}$ shotcrete, with a high-tensile diamond mesh, type MINAX ${ }^{\circledR} \mathrm{G} 80 / 4$ applied over the top, anchored with $\varnothing 25 \mathrm{~mm}$ bolts. The second step consisted of a thin layer of shotcrete (30 mm thickness) with a high-tensile diamond mesh, MINAX ${ }^{\circledR} \mathrm{G} 65 / 4$ over the top, anchored with cable bolts (seven strands) up to $4 \mathrm{~m}$ long, arranged radially, as shown in Figure 11(a).

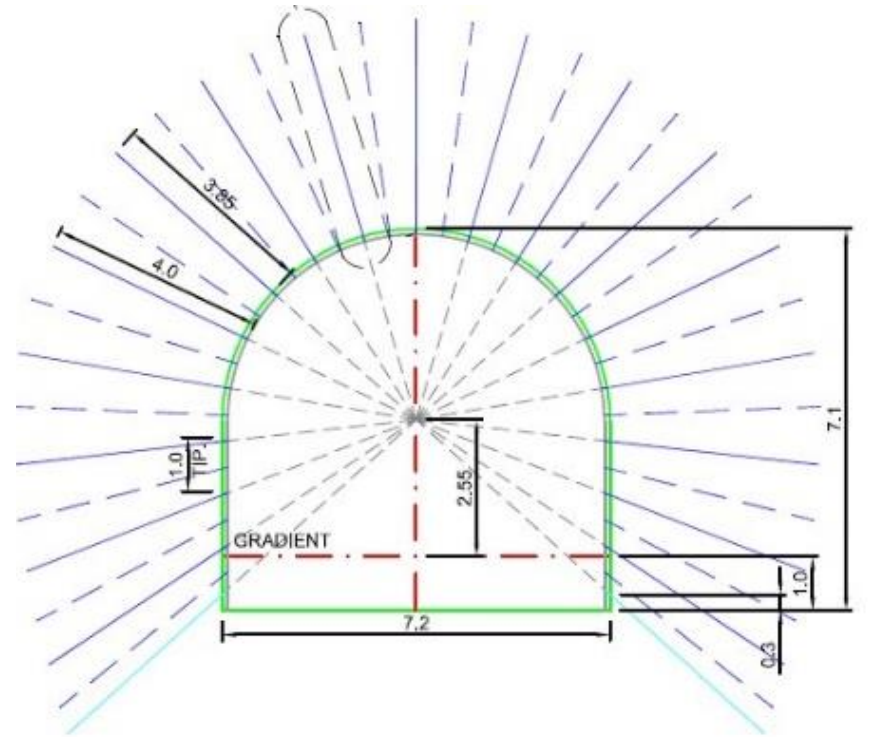

(a)

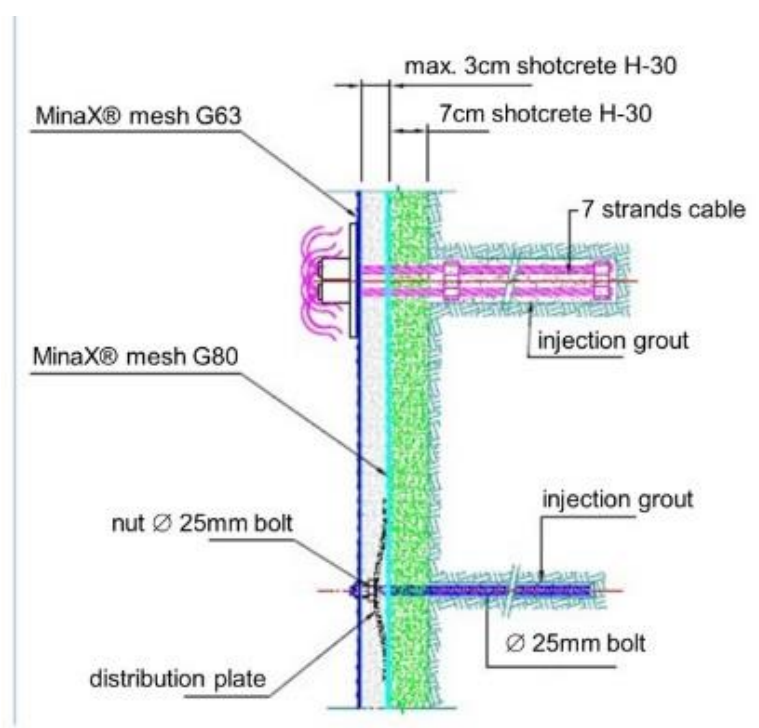

(b)

\section{Figure 11 Surface support system used}

The contractor prepared a report including the key performance indicators (KPI). In Figure 12 both columns show the percentage of use regarding forecasted availability.

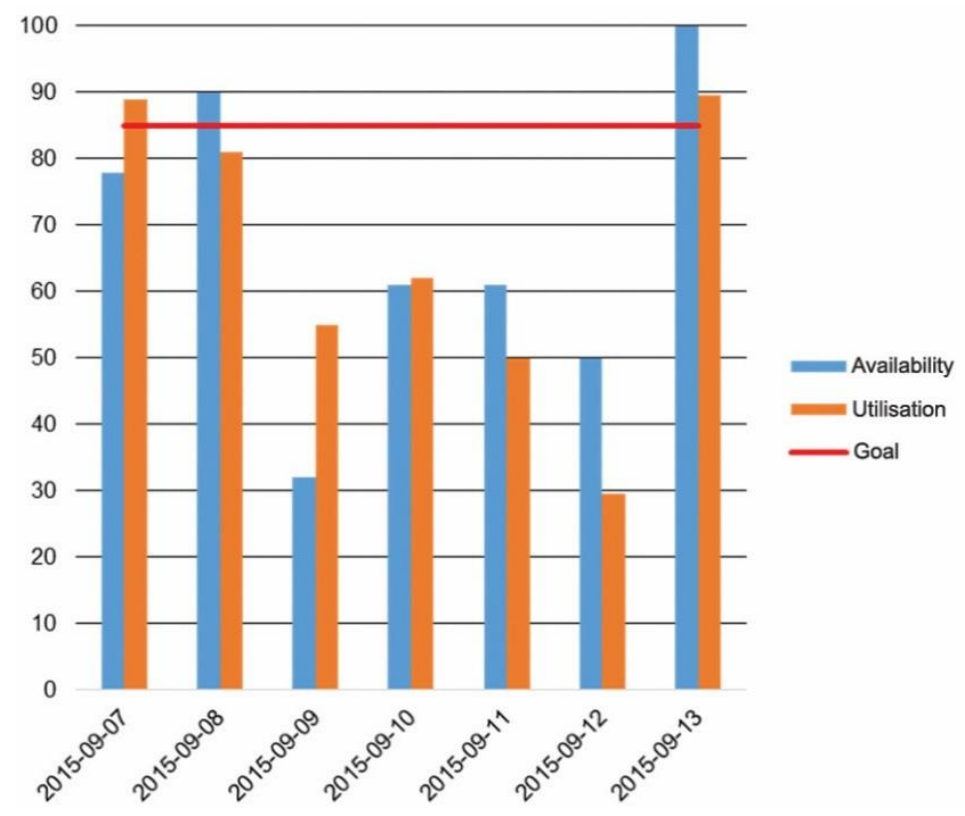

Figure 12 Mesha $^{\mathrm{TM}}$ availability and utilisation

The availability in week 37 was between 35 and 100\%, but the productive utilisation was reduced, due to certain issues described in Table 4. 
Table 4 Availability and utilisation MESHA ${ }^{\mathrm{TM}}$

\begin{tabular}{|c|c|}
\hline Date & Problem description \\
\hline 09 Sept & Strike by contractors \\
\hline 10 Sept (Shift A) & $\begin{array}{l}\text { Failure of sensor in lubrication system/continuity test of grouting } \\
\text { device/repair of grouting pump }\end{array}$ \\
\hline 11 Sept (Shift A) & Decision to adjust rolls back into original position \\
\hline 11 Sept (Shift B) & No water \\
\hline 12 Sept (Shift A) & Failure of rotation motor \\
\hline 12 Sept (Shift B) & No water \\
\hline
\end{tabular}

The installation times for bolts were between 2.7 bolts/ hour and 4.4 bolts/hour with an average of 3.7 bolts/hour, which is in line with the standard bolt installation times, given by the client, of an average of 3.6 bolts/hour (Figure 13). On 9 September 2015, an electrical grouting device was used, which allowed for an improvement in the installation times.

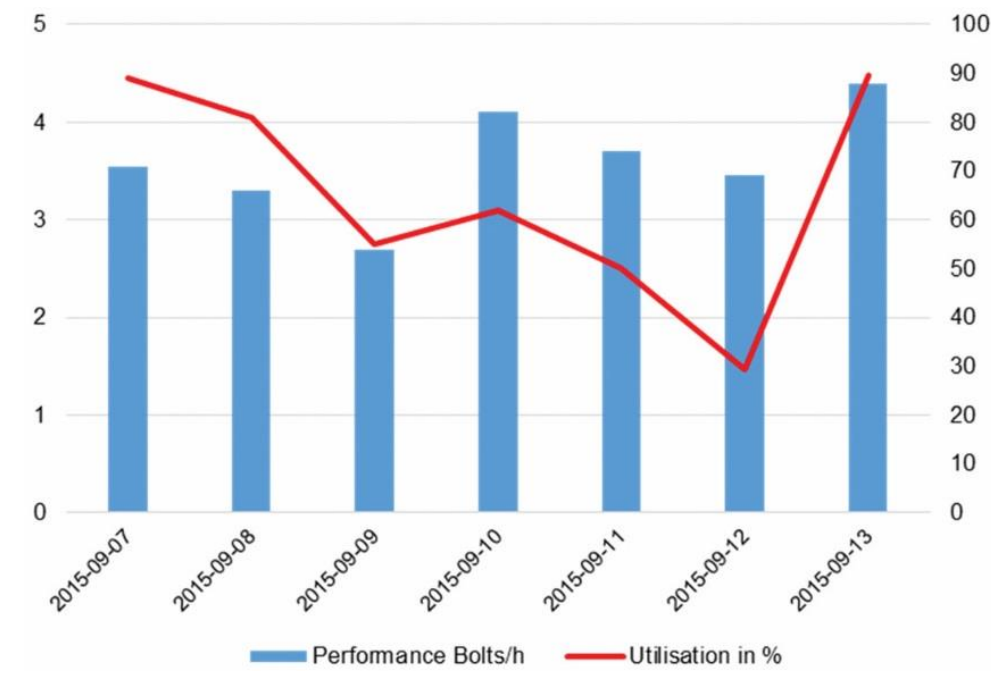

Figure 13 Installation performances of bolts on week 37

The productivity or installation performance has increased gradually from min 1.5 bolts/hour to 4.5 bolts/hour, as shown in Figure 14. The increase in installation times is undoubtedly part of the learning process.

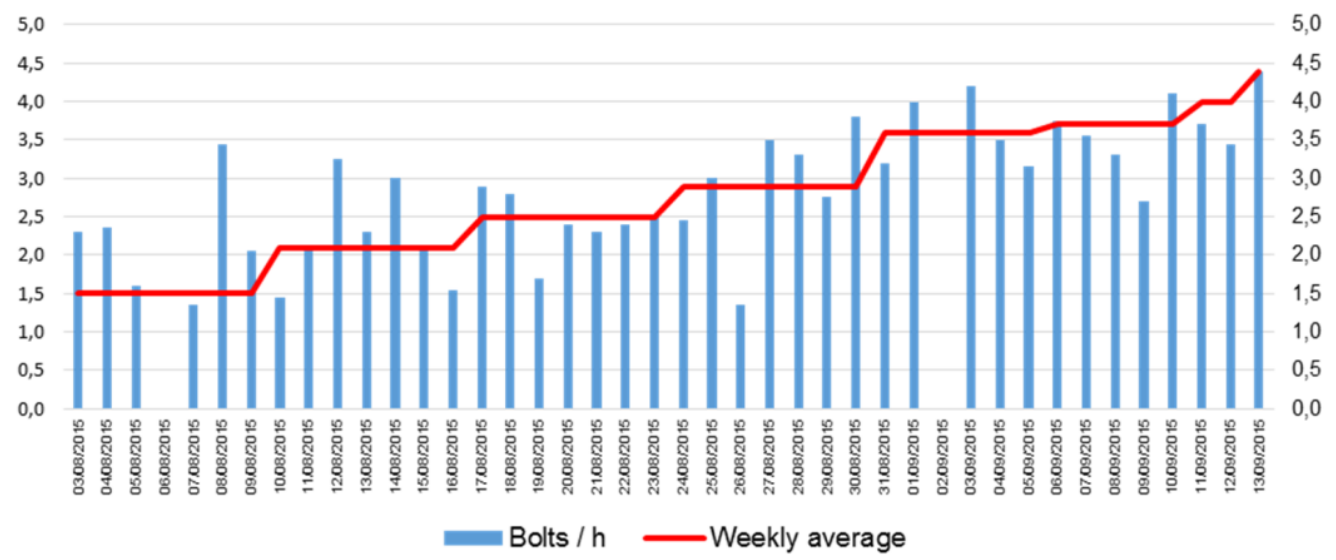

Figure 14 Installation performance of bolts installation 
Additionally, it was possible to quantify the lost time, classifying it into four groups: related to water, equipment, injection mortar trials and unexpected strike (common in the mining exploitations). As shown in Figure 15, the higher numbers in lost time has been associated with general problems related to equipment. Those were, in general, simple problems that should be reduced or eliminated if the system is going to be used on a regular basis. Although the impact has only been around $10 \%$, lack of water has been important in the performance, therefore, special attention should be paid to water supply requirements. Mandatory grout testing only equates to about $2 \%$ of lost time, and this should not even be considered as lost time as these tests is essential and mandatory.

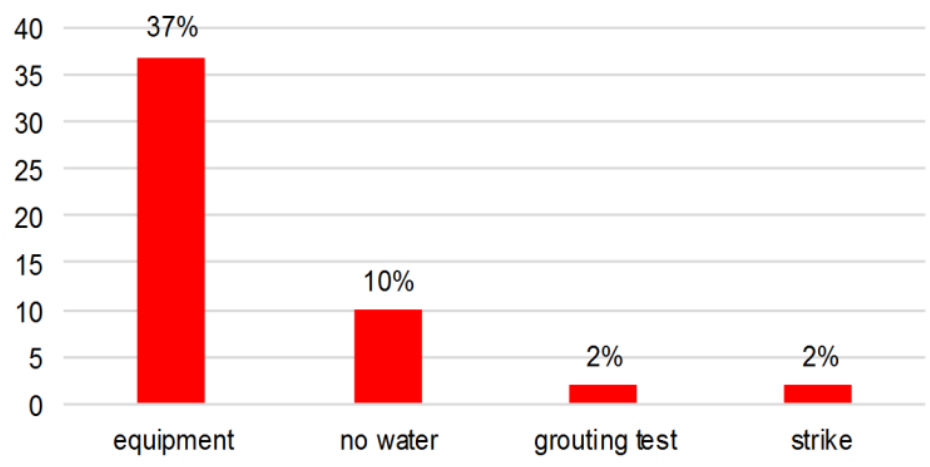

Figure 15 Total lost time in hours, shown in percentages

As previously mentioned, more than $35 \%$ of lost time was due to failure of the equipment. The highest number of failures has been associated with the equipment itself and, more specifically, with the injection system. There were no difficulties associated with the mesh handler (Figure 16).

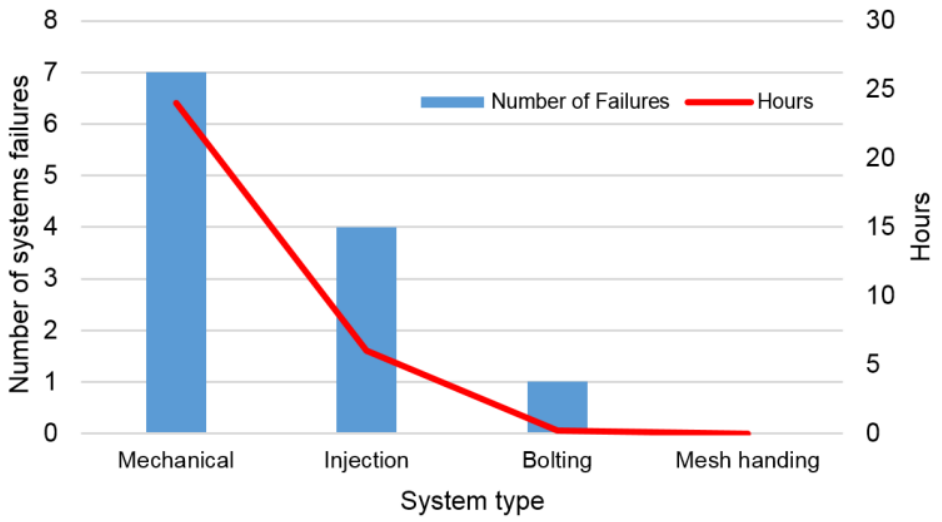

Figure 16 Failures per component

Figures 17 and 18 show, in more detail, the factors of lost time of the mechanical and injection system. Note, in Figure 17, that more than 39.25 hours (70\%) are associated to the hydraulic drilling device.

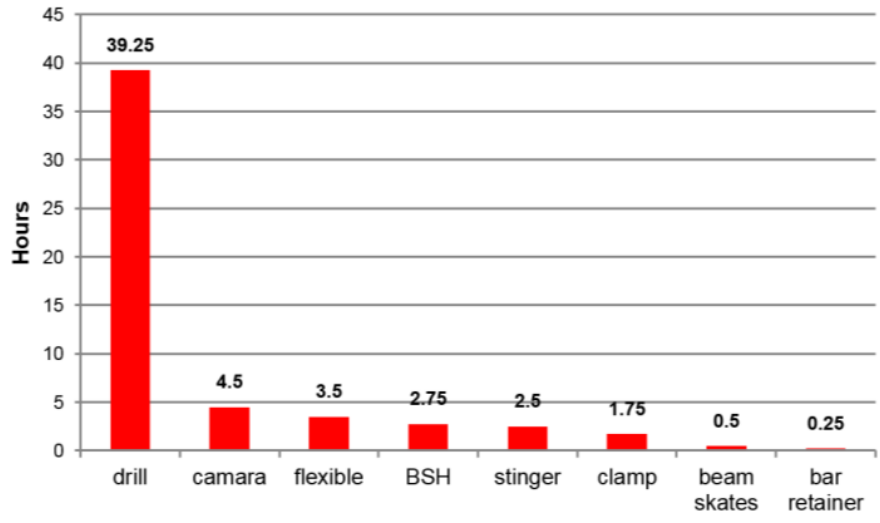

Figure 17 Boltec MC, failures in hours 
The pie chart in Figure 18 shows that more than $70 \%$ of the problems in the grouting system have been associated to the wear of gaskets or seals for the cement mortar.

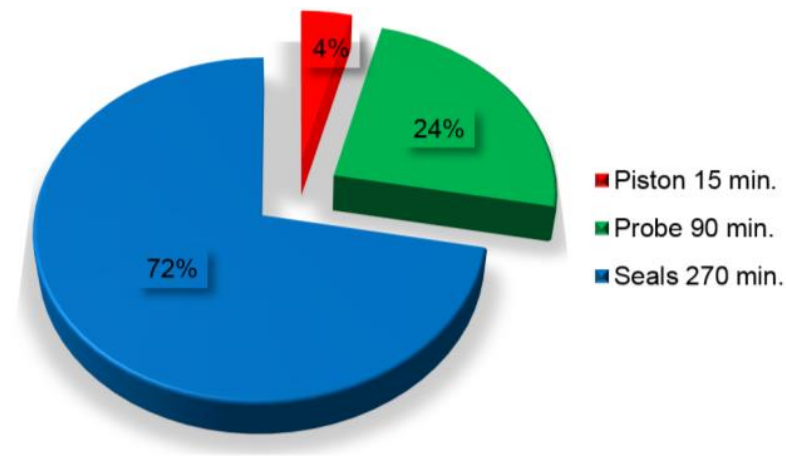

Figure 18 Failures in the injection system

Being aware of those statistics and knowing where the main lost time occurred, they can be included in the regular equipment check-up to reduce possible lost time. Therefore, the productivity and efficiency of the installation process should increase.

\section{$4 \quad$ Concluding remarks}

After successful laboratory testing of high-tensile chain link mesh under both static and dynamic conditions, it was shown that this kind of mesh is suitable for ground support in potential rockburst areas. In contrast to shotcrete, the rock remains visible for inspection by the geotechnical personnel. Due to the use of the MESHA $^{\mathrm{TM}}$ installation device, this light but strong mesh can be installed in a fully mechanised way. To achieve an increase in performance overall, it is necessary to improve on the factors that had a major impact on the lost time, such as failures associated with the mechanical and the grouting systems and other associated factors, such as lack of water, which are more logistical issues. Improvement of the factors causing delay will make the automatized application method of the mesh using the MESHA ${ }^{\mathrm{TM}}$ system, an efficient and safe tool. It can be concluded that both the high-tensile chain link mesh and its fully mechanised installation can increase the safety of mining personnel, the quality of the installed ground support, and the performance, due to a reduction in personnel and increasing the speed of mining development.

\section{References}

Luis Fonseca, R, Laguna, L \& Muñoz, B 2009, 'Comparative analysis of the mechanical properties of the steel membranes used in the slope stabilization', VII National Symposium on Unstable Hills and Slopes, Barcelona, Spain.

Morton, E, Thompson, A, Villaescusa, E \& Roth, A, 2007, 'Testing and analysis of steel wire mesh for mining applications of rock surface support', Proceedings of the 11th International Congress on Rock Mechanics, International Society for Rock Mechanics, Lisboa.

Player, JR, Villaescusa, E \& Thompson, AG 2004, 'Dynamic testing of rock reinforcement using the momentum transfer concept', in E Villaescusa \& Y Potvin (eds), Proceedings of the Fifth International Symposium on Ground Support, 28-30 September 2004, Perth, CRC Press.

Player, JR, Thompson, AG \& Villaescusa, E 2008, 'Dynamic testing of reinforcement systems', Proceedings of the Sixth International Symposium on Ground Support, 30 March-3 April 2008, Cape Town, The Southern African Institute of Mining and Metallurgy, Johannesberg.

Roth, A, Windsor, C, Coxon, J \& de Vries, R 2004, 'Performance assessment of high-tensile steel wire mesh for ground support under seismic conditions', in E Villaescusa \& Y Potvin (eds), Proceedings of the Fifth International Symposium on Ground Support, 28-30 September 2004, Perth, CRC Press, pp. 589-594.

Salfa Montajes 2015, Fortificación mecanizada equipo Boltec MC, El Teniente, Chile.

Thompson, AG, Player, JR, \& Villaescusa, E 2004, 'Simulation and analysis of dynamically loaded reinforcement systems', in E Villaescusa \& Y Potvin (eds), Proceedings of the Fifth International Symposium on Ground Support, 28-30 September 2004, Perth, CRC Press, pp. 341-355.

Tonkin, CJ, 2011, Time and motion study of sheeted wire meshing and rolled wire meshing systems, Goldfields South Deep, South Africa. Unican 2002, High tensile wires mesh characterization, Santander, Spain.

Villaescusa, E 2009, 'Dynamic testing of ground support elements', M349A Quarterly Progress Report March 2009, Western Australian School of Mines, Kalgoorlie. 